\title{
A TRIAL TO DETECT THE EFFECT OF STRAIN AND DIFFERENT SOURCES OF DRINKING WATER ON SOME PRODUCTIVE TRAITS IN BROILER CHICKS
}

Shimaa M. Shaker ${ }^{{ }^{*}}$, El-Safty S.A. ${ }^{2}$, Shoureap, U.A. ${ }^{2}$ and Zienb, El- Awamry ${ }^{1}$

1. The Regional Center for Food \& Feed (RCFF), Agriculture Research Center, Giza, Egypt.

2. Poultry Production Dept., Fac. of Agric., Ain Shams Univ., P.O. Box 68, Hadyek Shoubra11241, Cairo, Egypt

*Corresponding author: shaimaashaker82@gmail .com

Received 24 October, 2018,

Accepted 18 November, 2018

\begin{abstract}
The main goal of this experiment was to evaluate the effect of broiler strain and source of drinking water on some performance traits (body weight and carcass traits). Sample of water were taken from two different location sources, Giza governorate (as Nile water) and Qalubia governorate (as well water or ground water). Three different broiler strains were used in this study (Arbor acres, Hubbard and Cobb). Lead concentration (as a heavy metal element) and bacteriological analysis (total bacteria and fecal coliforms) in both water and carcass were carried out. The main results obtained can be summarized as follow: Arbor acres strain recorded the heaviest body at most ages compared to the other strains, the difference was highly significant at 5 and 6 weeks of ages. Total bacteria were significantly high in ground water compared to Nile water. Conversely, Coliforms bacteria count was significantly high in Nile water compared to ground water source. Regardless strain type, high positive correlation between lead concentration in drinking water and lead concentration in liver, kidney and carcass weight was observed
\end{abstract}

Key words: Productive traits, Broiler chicks

\section{INTRODUCTION}

Water is a vital element for life. For many kinds of poultry, water helps in digestion, absorption, elimination the harmful substances and excess salts by the kidney and supports the endocrine gland's function (Barney and Van Horn, 2003). Birds consumed about $40 \%$ of the drinking water to regulate their body temperature and to remain it constant at $42^{\circ} \mathrm{C}$ (Allam, 1986). (Carter and Sneed, 1996) stated that the quality of water for poultry is very important, where, as an increase in the salt content of well water above the optimum level leads to adverse, devastating and some pathological expression on birds resulting in high mortality and elimination. However, consuming contaminated poultry with heavy metals is very dangerous due to be accumulated of its heavy metal residues in chicken tissues and organs (EISarha and Hussein, 1994). (Vodela et al 1997) reported that increasing levels of drinking water contaminants such as Arsenic, Cadmium and Lead in the existence of low levels of vitamins and minerals in the diet resulted in a deterioration of natural, humoral and cell - immune response in turn poultry health at all.

\section{MATERIALS AND METHODS}

This study was carried out at Poultry Breeding Farm, Poultry Production Department, Faculty of Agriculture, Ain Shams University. The aim of this experiment was to evaluate the effect of different water sources on some productive performance in broilers strains.

Three genetic lines of broiler chicks (110 hubbard, 110 cobb and 110 arbor acres) were reared under similar managerial, environmental and hygienic conditions. They were brooded and raring in floor from hatching to 6 weeks of age. At one weeks of age, 120 chicks (30 each) were randomly 

productive traits in broiler chicks

This is true, due to that the heavier body weight will in turn has heavier carcass weight. The previous result is a reflection to the results of body weight trait. Regarding the estimates of liver weight in the studied strains, there was a significant difference among strains in such trait. hubbard strain recorded the highest value, while cobb birds had the lowest values, but arbor acres chicks had intermediate figures. Concerning the kidney weight, there was no significant difference among hybrids in such trait.

Table 2. Carcass, liver and kidney weights, gram (Mean \pm SE) of Arbor Acres, Hubbard and Cobb broiler strains.

\begin{tabular}{|ccccc|}
\hline \multirow{3}{*}{ Trait } & \multicolumn{3}{c|}{ STRAIN } & \\
\cline { 2 - 4 } & $\begin{array}{c}\text { Arbor } \\
\text { Acres }\end{array}$ & $\begin{array}{c}\text { Hub- } \\
\text { bard }\end{array}$ & Cobb & Prob. \\
\hline Carcass weight, g & $1363.5^{\mathrm{a}}$ & $1325.5^{\mathrm{b}}$ & $1306.0^{\mathrm{b}}$ & * \\
& \pm 95.4 & \pm 82.5 & \pm 88.4 & \\
Liver weight, g & $51.63^{\mathrm{b}}$ & $57.5^{\mathrm{a}}$ & $44.63^{\mathrm{c}}$ & ** \\
& \pm 3.9 & \pm 4.2 & \pm 2.8 & \\
Kidney weight, g & 6.73 & 6.88 & 6.15 & NS \\
& \pm 0.49 & \pm 0.50 & \pm 0.40 & \\
\hline
\end{tabular}

a,b values with different superscripts are statistically different within the same raw.

${ }^{*} P \leq 0.05 \quad$ ** $P \leq 0.01 \quad$ NS: not significant

With regard to chemical and bacteriological analysis of underground water gained from various sources (Nile and well water), Table (3) showed that there was no significant difference between the two sources of water for lead concentration. Generally, noxious chemicals like heavy metals include cadmium, lead, chromium, copper, nickel, etc., that pollute the soils, ground water, sediments and surface waters represent in soluble form. (Faiza Salem et al 2015). The two sources are somewhat the same in total bacterial. Whereas, the significant difference was observed in total bacterial count. Where, the ground water recorded more bacterial count compared to the Nile water. That means the ground water may be subjected to more contamination from environment surrounding (especially soil) rather than Nile water. Heavy metal contaminated soils and waterways is increasingly becoming an environmental, health, economic, and planning issue. (Ansari and Malik, 2001). The isolation of bacteria from soil samples was a reference that the estimated microorganisms were susceptive of growing in the existence of toxic heavy metals as lead (Singh et al 2010). The capability of microbial strains to grow in the presence of heavy metals could be helpful and facilitator in the soil treatment where microorganisms are immediately implicated in the decomposition of organic matter in biological operations for the treatment of soil and water, because often the adverse effect of heavy metals is a prevalent phenomenon that pass in the biological trial on water and soils (Verma et al 2001).

Table 3. Chemical and bacteriological analysis of water obtained from different sources.

\begin{tabular}{|c|c|c|c|}
\hline Parameters & $\begin{array}{l}\text { Nile (Giza } \\
\text { location) }\end{array}$ & $\begin{array}{l}\text { Well (Qalu- } \\
\text { bia location) }\end{array}$ & Prob. \\
\hline $\begin{array}{l}\text { Lead concentra- } \\
\text { tion, mg } \backslash \\
\text { Total bacteria, } \\
\mathrm{CFU}^{* *} / \mathrm{ml} \\
\text { Fecal coliforms, } \\
\mathrm{CFU} / \mathrm{ml}\end{array}$ & $\begin{array}{c}0.91 \pm 0.17 \\
6.75^{\mathrm{b}} \pm 0.23 \\
2.98^{\mathrm{a}} \pm 0.65\end{array}$ & $\begin{array}{c}0.92 \pm 0.19 \\
7.14^{\mathrm{a}} \pm 0.16 \\
1.27^{\mathrm{b}} \pm 0.40\end{array}$ & $\begin{array}{l}\text { NS } \\
* \\
*\end{array}$ \\
\hline \multicolumn{4}{|c|}{$\begin{array}{l}\text { a,b values with different superscripts are statistically different } \\
\text { within the same raw. }\end{array}$} \\
\hline
\end{tabular}

Conversely, was observed regarding fecal coliforms, the water from Nile recorded the highest figures compared to ground water counterpart. The previous result may be due to that this water may be contaminated with animal or human feces.

Table (4) revealed the chemical and bacteriological analysis of carcass, liver and kidney obtained from strains using different sources of water. Lead concentration in liver was slightly high in birds consumed ground water (well), especially in cobb birds. The difference between water locations or among strains was not significant in such trait. The same trend was realized in lead concentration in kidney. Regarding total bacterial count in carcasses, it could be noted that the carcasses from the birds consumed ground water have more bacterial count compared with the carcasses from those consumed Nile water. The hubbard birds recorded the highest values for such trait. Concerning the fecal coliforms bacteria, the previous trend was realized. That means the residues from bacteria or lead was slightly obvious when using well water compared to Nile water. Generally, it could be concluded that no significant difference was observed whether using Nile or Well water on the studied traits. 
Table 4. Chemical and bacteriological analysis of carcass obtained from strains.

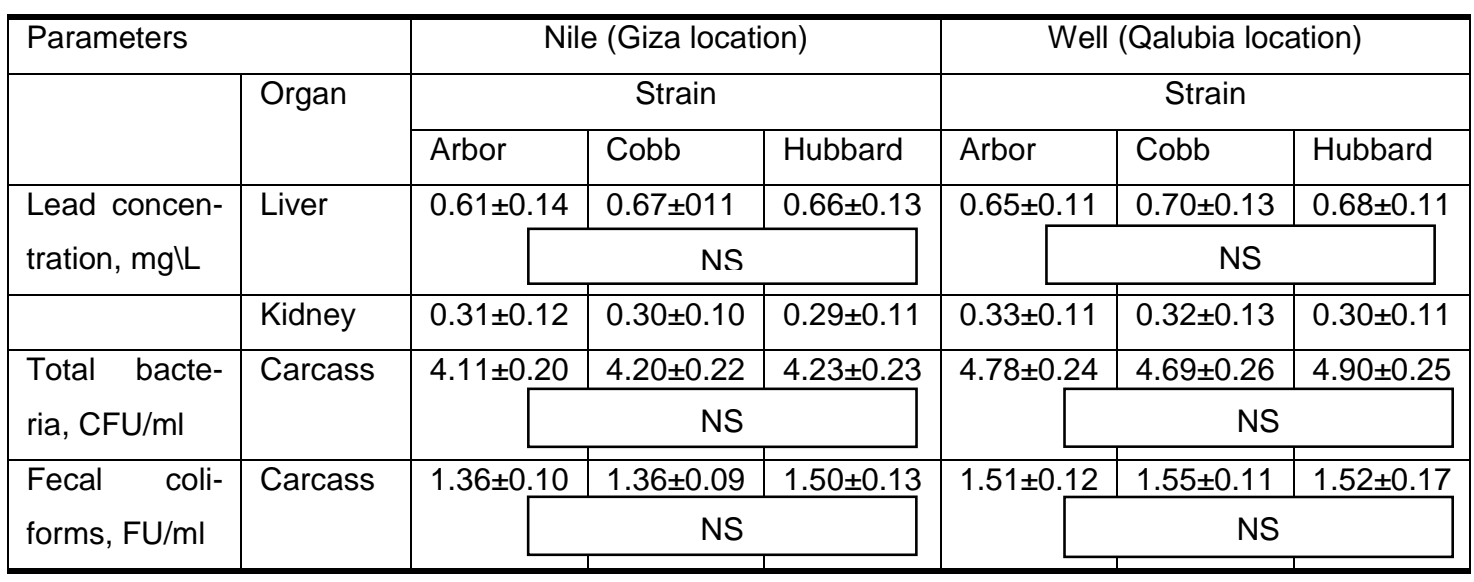

No significant difference (NS) was observed between locations or strains in the studied traits

Table (5) explained that regardless strain type, high positive correlation between lead concentration in drinking water and lead concentration in liver, kidney and carcass weight was observed. Also, the high and positive relationship was very clear among lead in both liver and kidney in one side and carcass weight in another side. The poisoning of these metal elements has two main forms, they have no known metabolic function but when current in the body damage normal cellular procedure leading to toxicity and the potency of these heavy metals to accumulate in biological organs, a process known as bio accumulated (Mariam et al 2004).

Table 5. Correlation coefficients among lead concentration in water and its concentrations in liver and kidney and different relations with carcass weight.

\begin{tabular}{|cccccc|}
\hline Trait & $\mathrm{Y}$ & $\mathrm{Y} 1$ & $\mathrm{Y} 2$ & $\mathrm{Y} 3$ & Stain \\
\hline lead in water & - & $0.75^{* *}$ & $0.75^{* *}$ & $0.84^{* *}$ & Arbor acre \\
$(\mathrm{Y})$ & - & $0.83^{* *}$ & $0.87^{* *}$ & $0.84^{* *}$ & Cobb \\
& - & $0.84^{* *}$ & $0.87^{* *}$ & $0.44^{* *}$ & Hubbard \\
\hline lead in liver & - & - & $0.81^{* *}$ & $0.77^{* *}$ & Arbor acre \\
$(\mathrm{Y} 1)$ & & & $0.89^{* *}$ & $0.88^{* *}$ & Cobb \\
& - & - & $0.89^{* *}$ & $0.52^{* *}$ & Hubbard \\
\hline Lead in kidney & - & - & - & $0.81^{* *}$ & Arbor acre \\
$(\mathrm{Y} 2)$ & & & - & $0.97^{* *}$ & Cobb \\
& & & & $0.59^{* *}$ & Hubbard \\
\hline Carcass weight & & & - & Arbor acre \\
(Y3) & & & & & Cobb \\
& & & & & Hubbard \\
\hline
\end{tabular}

They inferred that the oxidative stress prompt by cadmium and lead plays a function in decreasing the execution of chickens. This come because the metals, once taken up into the body is stored in particular organs, for example the liver and the kidney (Demerezen et al 2006).

\section{REFERENCES}

Allam, S., 1986. Chicken Rearing and Caring. $7^{\text {th }}$ Ed. Egyptian Anglo Publication. Cairo, Egypt. Cited by El-Ghazaly N., Bin Dohaish E. and Alsolamy S. (2008). J. Biology Sc., 11, 559-564.

Ansari. M.I. and Malik. A., 2010. Seasonal Variation of Different Microorganisms with Nickel and Cadmium in the Industrial Wastewater and Agricultural Soils. J. Bacteriolog, 167, 151163.

Barney, H. Jr. and Van Horn, H.H., 2003. Water and its importance to animals. Florida Coop. Ext. Serv. Univ. of Florida, Gainesville, pp. 1-8.

Carter, T.A. and Sneed, R.E. 1996, Drinking water quality for poultry. North Carolina coop. Ext. Serv., No. PS and T=42. Cited by El-Ghazaly, et al., 2008.

Demirezen, O. and Uruc, K., 2006. Comparative study of trace elements in certain fish, meat and meat products. Food Chemistry, 32, 215222.

Elisabeth, G., Buyse, J., Sartori, J.R., Loddi, M.M. and Decuypere, E. 2012. Metabolic disturbance in Male broiler of different strains. Poultry Science, 91(11), 2942-2948.

El-Sarha, A.I. and Hussein H.K. 1994. Pollution of ground water by mercury and its residues in 

productive traits in broiler chicks

chicken tissue. Bull. Fac. Sci. Alex. Univ., 34 (2), 187-197.

Faiza Saleem, Fareeha Aftab, Rooma Adalat and Neelma Munir 2015. Isolation of Lead Resistant Bacteria from Lead Contaminated Soil Samples Collected from Sundar Industrial Estate and their Potential Use in Bioremediation. J. Chem. Soc. Pak., 37(3), 495-501

Mariam, I.S. and Nagre, S., 2004. Distribution of some trace and macro minerals in beef, mutton and poultry. International Journal of Agric. and Biology, 6, 816-820.

Price, C.J., Lott, B.D. and Morgan, G.W. 1999. Performance of four commercial broiler strain crosses fed graded levels of amino acids. Poult. Sci $88^{\text {th }}$ Annual Meeting Abstract August, pp. 8-11.
Singh, V., P. K. Chauhan, R. Kanta, T. Dhewa and V. Kumar, 2010, Isolation and Characterization of Pseudomonas Resistant to Heavy Metals Contamination, Int. J. Pharm. Sci. Rev. Res., 3, 164-167.

Verma, T., Srinath, T., Gadpayle R.U., Ramtake P. W., Hans R.K. and Garg S.K. 2001. Chromate Tolerant Bacteria Isolated from Tannery Effluent. Biores. Technol., 78, 31-35.

Vodela, J.K., Renden J.A., Lenz S.D., Mcelhenney W.H. and Kemppainen B.W., 1997. Drinking water contaminants (arsenic, cadmium, lead, benzene and trichloroethylene). 1. Interaction of contaminants with nutritional status on general performance and immune function in broiler chickens. Poult. Sci., 76, 1474-1492. 



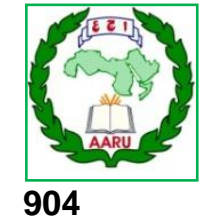

المؤتمر الرابع عثر لبحوث التنمية الزراعية، ماعدة

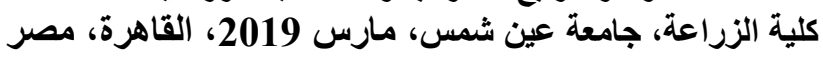
مجلد(27)، عدد (1)، عدد خاص مارس، مارس 2019 (204-899، Website: http://strategy-plan.asu.edu.eg/AUJASCl/

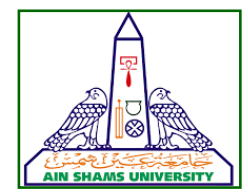

تجربة تكثف عن تأثثر السلالة ومصادر مختلفة من مياه الشرب على بعض الصفات الإنتاجية في دجاج اللحم

$$
\begin{aligned}
& \text { شيماء محمد شاكر 1-- صلاح الدين الصفتى 2- أسامة على شوريب²- زينب العوامري } 1
\end{aligned}
$$

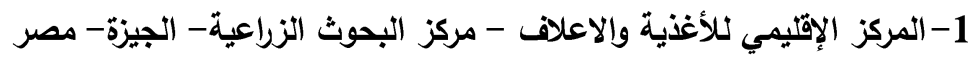

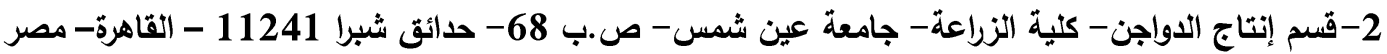

*Corresponding author: shaimaashaker82@gmail .com

المياه والذبيحة، وقد تم قياس تركيز الرصاص (كعنصر

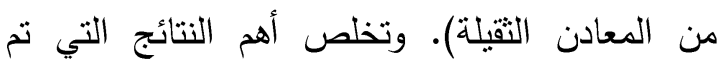

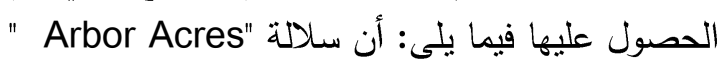
تسجل أنقل وزن جسم في معظم الإعمار مقارنة بالسلالات الأخرى، والفرق كان معنوى في في الأعمار

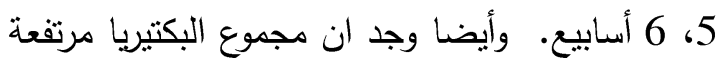
إلى حد كبير في المياه الجوفية مقارنة بمياه النيل. على العكس من ذلك ،كان عدد بكتيريا القولون

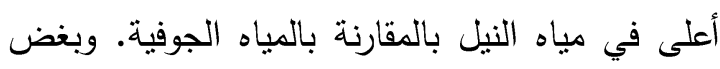

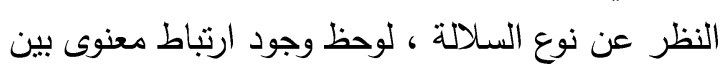
تركيز الرصاص في مياه الثرب وتركيز الرصاص في في لوني لوني وزن الكبد والكلى والذبيحة.

الكلمات الدالة: سلالات الإنتاج، دجاج التسمين

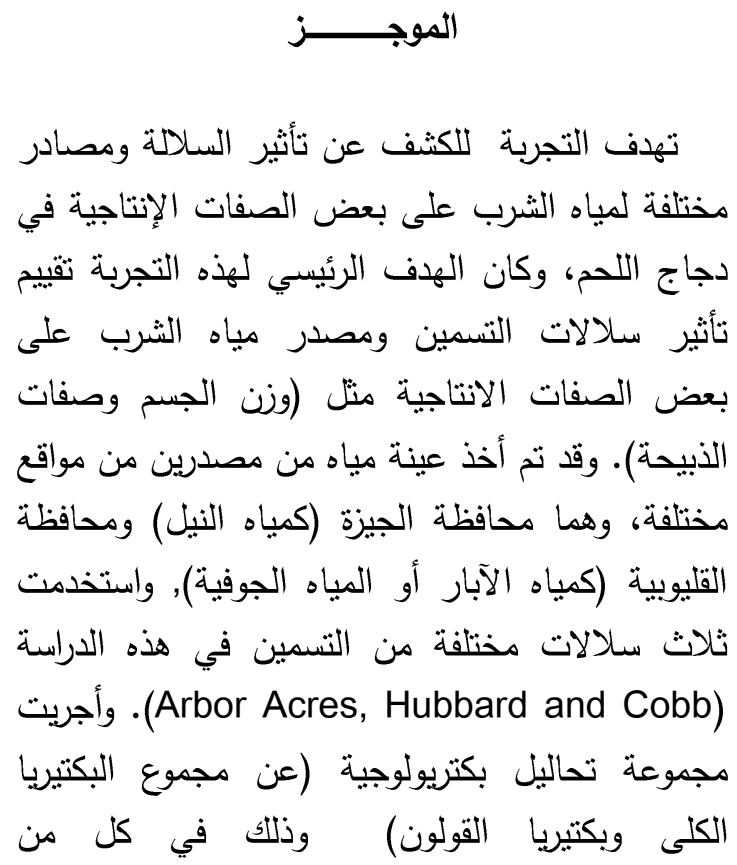

تحكيم: ا.د أحمد جلال السيد

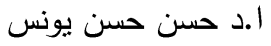

